\title{
A Morphometric Survey among Three Iranian Horse Breeds with Multivariate Analysis
}

\author{
M. Hosseini, H. M. Shahrbabak*, M. B. Zandi, \& M. H. Fallahi \\ Department of Animal Science, Faculty of Agriculture and Natural Resources, University of Tehran, \\ Karaj, Iran \\ (Received 07-08-2016; Reviewed 21-09-2016; Accepted 10-10-2016)
}

\begin{abstract}
Three Iranian horse breeds, Turkoman, Caspian, and Kurdish, are the most important Iranian horse breeds which are well known in all around of the world because of their beauty, versatility, great stamina, and intelligence. Phenotypic characterization was used to identify and document the diversity within and between distinct breeds, based on their observable attributes. Phenotypic characterization and body biometric in 23 traits were measured in 191 purebred horses belonging to three breeds, i.e. Turkoman (70 horses), Kurdish (77 horses), and Caspian (44 horses). Caspian breed was sampled from the Provinces of Alborz and Gilan. Kurdish breed was sampled from the Provinces of Kurdistan, Kermanshah, and Hamadan. Turkoman breed was sampled from the Provinces of Golestan, Markazi, and Isfahan. Multivariate analysis of variance (MANOVA) was implemented. In addition, Canonical Discriminate Analysis (CDA), Principal Component Analysis (PCA), and Custer analysis were executed for assessing the relationship among the breeds. All statistical analysis was executed by SAS statistical program. The results of our investigation represented the breeds classification into 3 different classes (Caspian, Turkoman, and Kurdish) based on different morphometrical traits. Caspian breed with smaller size in most variables was detached clearly from the others with more distance than Kurdish and Turkoman breeds. The result showed that the most variably trait for classification was Hind Hoof Length. Adaptation with different environments causes difference in morphology and difference among breeds. We can identify and classify domestic population using PCA, CDA, and cluster analysis.
\end{abstract}

Key words: morphometric, Iran, horse, breed, PCA

\section{ABSTRAK}

Turkoman, Caspian, dan Kurdish, merupakan tiga bangsa kuda Iran paling penting dan terkenal di dunia karena keindahan, kelincahan, ketangguhan, dan kepintarannya. Karakteristik fenotipik digunakan untuk mengidentifikasi dan mendokumentasi perbedaan antarbangsa berdasarkan atribut yang dapat diamati. Sejumlah 23 sifat karakteristik fenotipik dan biometrik tubuh diukur pada 191 kuda yang terdiri atas 3 bangsa, yaitu: Turkoman (70 kuda), Kurdish (77 kuda), dan Caspian (44 kuda). Sampel untuk bangsa Caspian berasal dari Provinsi Alborz dan Gilan; bangsa Kurdish dari Provinsi Kurdistan, Kermanshah, dan Hamadan; sedangkan bangsa Turkoman dari Provinsi Golestan, Markazi, dan Isfahan. Multivariate analysis of variance (MANOVA) digunakan untuk menganalisis data. Canonical discriminate analysis (CDA), principal component analysis (PCA), dan cluster analysis digunakan untuk menilai hubungan antarbangsa. Semua analisis statistik dikerjakan menggunakan program statistik SAS. Hasil penelitian mengklasifikasikan 3 bangsa kuda berdasarkan sifat morfometrisnya, yaitu: Caspian, Turkoman, dan Kurdish. Bangsa Caspian memiliki ukuran tubuh lebih kecil dibanding dua bangsa lainnya, yaitu Kurdish dan Turkoman. Hasil penelitian juga menunjukkan bahwa peubah sifat yang paling berbeda pengklasifikasiannya adalah panjang kuku belakang. Adaptasi dengan lingkungan yang berbeda menyebabkan perbedaan pada morfologi antarbangsa. PCA, CDA, dan cluster analysis dapat digunakan untuk mengidentifikasi dan mengklasifikasikan populasi domestik.

Kata kunci: morfometrik, Iran, kuda, bangsa, PCA

*Corresponding author:

E-mail: hmoradis@ut.ac.ir 


\section{INTRODUCTION}

Native horse breeds are national precious wealth in each country; keeping and rearing of them is valuable (Hendricks, 2007). Breeds of Turkoman, Kurdish, and Caspian are the most important Iranian horse breeds which are used for different goals. Turkoman breed is used for jumping and course performances, because of its beauty, great endurance, and speed. Caspian, as one of the oldest breeds, is used for riding, training to children, because of its small body size. These beautiful ponies have strength, speed, and great versatility making them a wonderful all round pony. Kurdish breed is used in chogan and deressage because of its bravery.

The distribution of each species is not uniform and it may include different breeds; usually all of which appear with different morphological and biological characters and traits. In the view point of the environment, ignoring the diversity of inner species, like the presence of different breeds, could result in the peril species (Ruggiero et al., 1999). One of the best methods in investigating horse breeds is morphometric method. Comparing to molecular method, this method has noticeable advantages including low cost, the absence of pollution, and easy to study as well as elimination of personalization deal (Slice, 2007). The same is true for horse breeds from many years of age (Hendricks, 2007).

So far some studies are associated with horse morphometric. Gabriel et al. (1998) revealed significant differences of equine navicular bone among different horse breeds. Also Cervantes et al. (2009) discovered significant differences in shape and size of the Arabian horse in Spain. One of the most important studies associated with morphometric of horse breeds is the study of Brooks et al. (2010) using 65 horse breeds, including Caspian breed. According to their results, Caspian breed was very close to such breeds as the Welsh pony and Shetland pony. In another study Weller et al. (2006) showed a significant difference of joint angles and the lengths of segment among racehorses in France and Ireland. Morphometric studies of horse breeds were not limited to the outer body organs. Therefore, Carter et al. (2009) revealed that tendon ligament measures of Thoroughbreds were significantly higher than Arabian horse.

All of the above mentioned studies were applied to answer this question whether there is any morphometric difference among horse breeds? If so, how it is? By this way, a better identification of breeds, their evolution process as well as their sibling relationship could be obtained.

Therefore, the aims of this investigation were to assess the presence of morphometric differences and how the morphometric differences as well as sibling relationships among Iranian breeds i.e., Turkoman, Kurdish, and Caspian.

\section{MATERIALS AND METHODS}

This investigation was carried out based on a total of 191 purebred horses belonging to three breeds; Turkoman (70 horses), Kurdish (77 horses), and Caspian (44 horses). The experimental horses were sampled from the Provinces of Alborz and Gilan for Caspian breed and the Provinces of Kurdistan, Kermanshah, and Hamadan for Kurdish Breed, and the Provinces of Golestan, Markazi, and Isfahan for Turkoman breed (Figure 1). Also to avoid a bias in the results of the re-

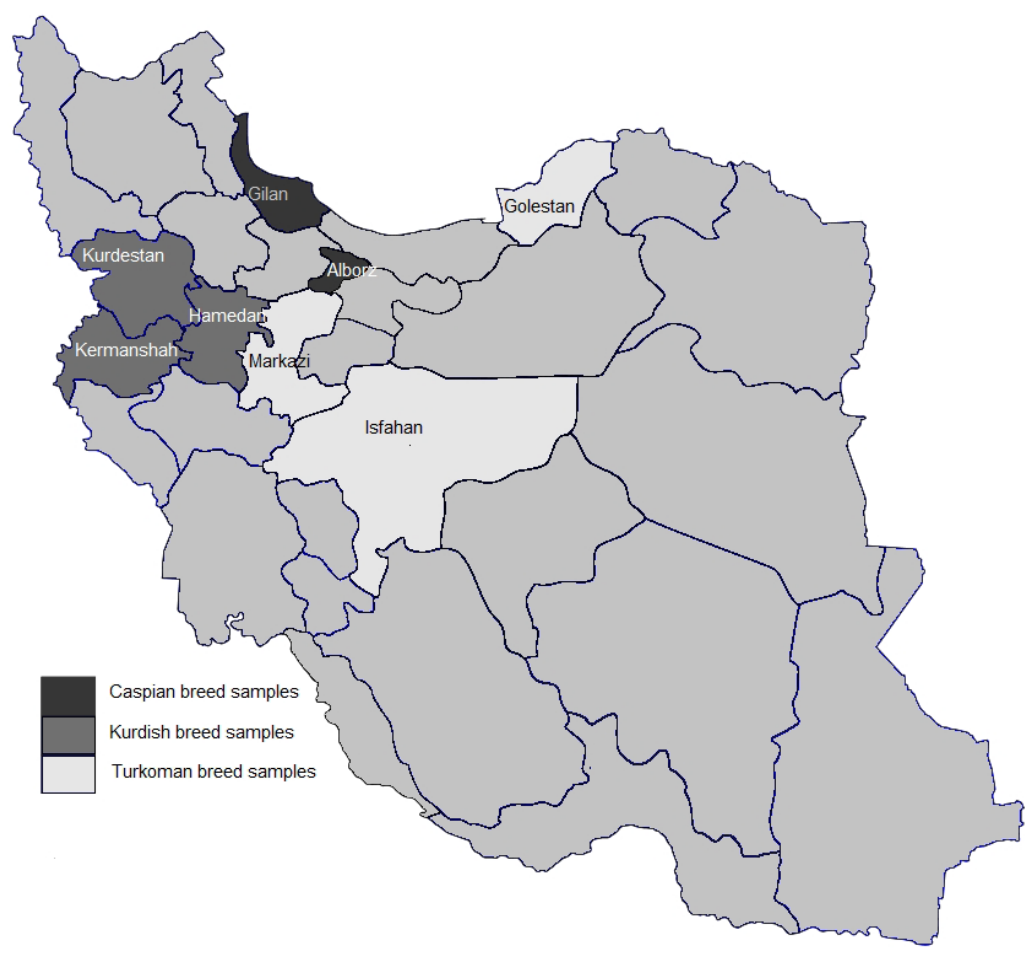

Figure 1. Sampling location for three different horse breeds (Caspian, Kurdish, and Turkoman) in some provinces in Iran 
search we prefer to select the animals with the age of 4-6 years and different sexes but at first the samples were analyzed with ANOVA proc to determine the effect of different sexes on morphometrical traits.

Twenty-three morphometric traits were measured by standard caliper and measuring tapes (Figure 2). Figure 2 shows that morphometric variables are as follows:

head length (1), ear length (2), neck length (3), height (4), fore arm length (5), fore cannon length (6), fore pastern length (7), fore hoof length (8), fore cannon midpoint circumference (9), fore pastern circumference (10), space under horse (11), length of croup to dock (12), gaskin length (13), hind cannon length (14), hind pastern length (15), hind hoof length (16), hind cannon midpoint circumference (17), hind pastern circumference (18), barrel girth at heart (19), circumference at base (20), eye to eye width (21), chest width (22), and pelvis width distance (23). All of the traits were measured in conformity with centimeter $(\mathrm{cm})$.

In order to proofing the presence of differences among the breeds, multivariate analysis of variance (MANOVA) was implemented. Also, canonical discriminate analysis (CDA), principal component analysis (PCA), and Cluster analysis were executed for assessing the relationships among the breeds. Analysis of variance (ANOVA) was done individually for each morphometric variable in order to assess the presence of difference in each variable among the breeds. All statistical analysis

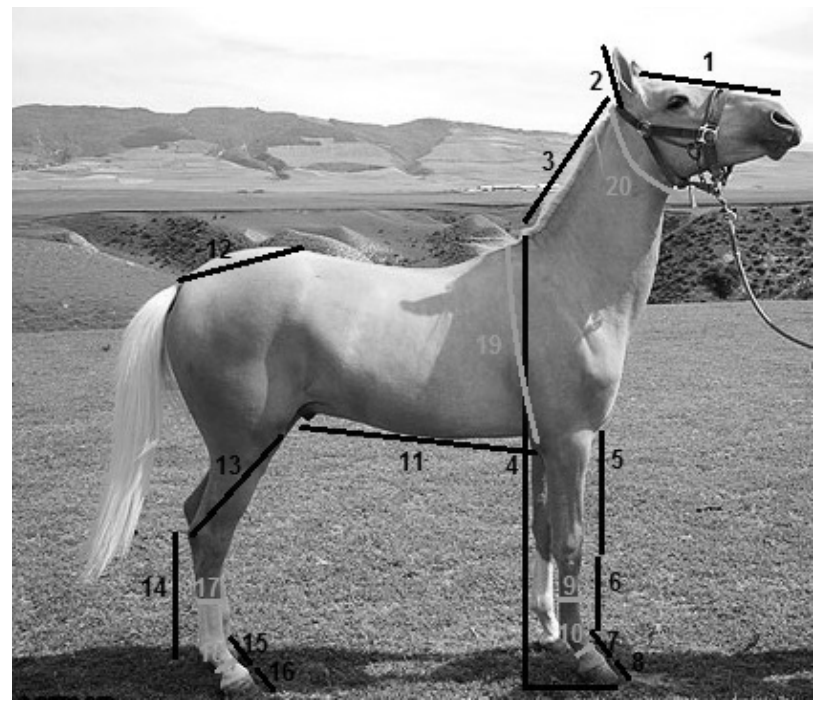

Figure 2. Morphometric traits. Morphometric variables are as follows (missing features: 21, 22, 23): head length (1), ear length (2), neck length (3), height (4), fore arm length (5), fore cannon length (6), fore pastern length (7), fore hoof length (8), fore cannon midpoint circumference (9), fore pastern circumference (10), space under horse (11), length of croup to dock (12), gaskin length (13), hind cannon length (14), hind pastern length (15), hind hoof length (16), hind cannon midpoint circumference (17), hind pastern circumference (18), barrel girth at heart (19), circumference at base (20), eye to eye width (21), chest width (22), and pelvis width distance (23). was executed by SAS statistical program, V. 9.3 (SAS Institute, 2013). The multivariate statistic model for this research was as follow:

$\mathrm{Y}_{\mathrm{ijklm}}=\mu+\mathrm{S}_{\mathrm{i}}+\mathrm{B}_{\mathrm{j}}+\mathrm{P}_{\mathrm{k}}+\mathrm{e}_{\mathrm{ijklm}}$

where S is sex effect, B is breed effect, $\mathrm{P}$ is Province effect, $\mathrm{A}$ is age effect, and e is vector of error terms or random deviations from the expected value. This below equation was used to calculate the contribution of each attribute in the main components (PCi):

$\mathrm{R}_{\mathrm{PC}, \mathrm{Xj}_{\mathrm{j}}}=\mathrm{g}_{\mathrm{ij}} \times \sqrt{ } \mathrm{li} / \mathrm{s}^{2}$

where $\mathrm{R}_{\mathrm{PC}, \mathrm{X}_{\mathrm{j}}}$ is correlation coefficient between $\mathrm{i}^{\text {th }}$ main components (PCi) and $j^{\text {th }}$ variable, li is $\mathrm{PC}_{\mathrm{i}}$ variance and $S^{2}, X_{j}$ variance. We calculated the following equation, part of the $\mathrm{X}_{\mathrm{j}}$ changes that is justifiable by the $\mathrm{PC}_{\mathrm{i}}$ :

$\mathrm{PC}_{\mathrm{i}}=\mathrm{g}_{11} \mathrm{X}_{1}+\mathrm{g}_{12} \mathrm{X}_{2}+\ldots \ldots \ldots . .+\mathrm{g}_{1 \mathrm{p}} \mathrm{X}_{\mathrm{P}}$

\section{RESULTS}

MANOVA demonstrated high significant differences among the breeds (Wilks' Lambda: 0.0048, F: 36.69, df1: 46, df2: 126, $\mathrm{P}<0.0001)$. A scatter plot of canonical discriminate analysis (CDA) revealed that the breeds were apart to each other (Figure 3). The same is true for principal component analysis (PCA).

According to PCA, Hind Hoof Length had the most weight in PC1 (Table 1) that it was explained as much as $60 \%$. Scatter plot based on PC1 (component 1) and PC2 (component 2) (from $70 \%$ of the total variance) showed that the breeds were completely separated with each other; Caspian was placed thoroughly separated from each other, Turkoman and Kurdish were close to each other and they had a little bit overlap (Figure 4). The cluster analysis confirmed the results of PCA. Therefore, according to this analysis, Caspian breed was placed in a separate cluster and Turkoman and Kurdish breeds were placed in a unit cluster (Figure 5). The highest and the lowest morphological distances were between Caspian and Turkoman and between Kurdish and Caspian, respectively (Figure 6). Table 2 indicates means of all morphometric traits plus their standard deviation for each breed. ANOVA revealed significant differences in all traits, except three variables of eye to eye width, fore hoof length, and hind hoof length.

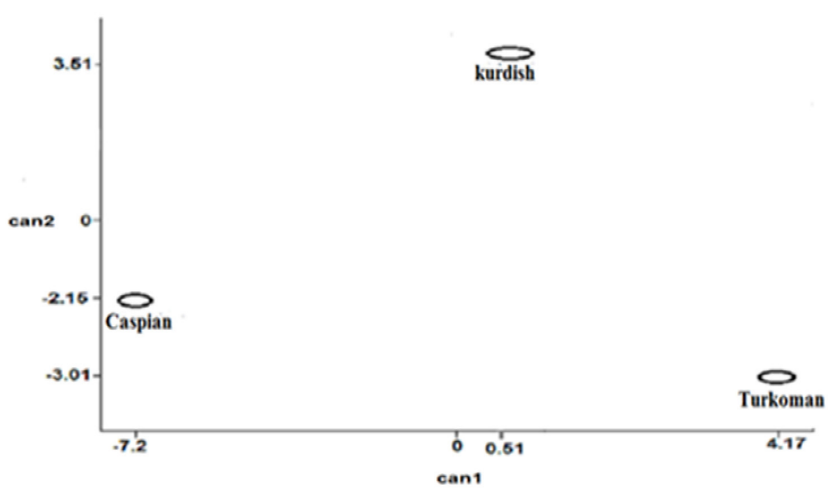

Figure 3. Scatter plot of canonical discriminate analysis (CDA) based on can 1 and can2 
Table 1. Contribution of each morphometric variable in three first components, the percentages within each component indicate contribution of each component in changes

\begin{tabular}{lccc}
\hline \multirow{1}{*}{\multicolumn{1}{c}{ Variables }} & \multicolumn{3}{c}{ Components } \\
\cline { 2 - 4 } & PC1 & PC2 & PC3 \\
& $(60 \%)$ & $(10 \%)$ & $(6 \%)$ \\
\hline Head length & 0.238 & -0.156 & -0.015 \\
Eye to eye width & 0.235 & 0.008 & 0.034 \\
Ear length & 0.174 & -0.081 & -0.314 \\
Neck circumference & 0.182 & 0.283 & 0.072 \\
Neck length & 0.172 & -0.036 & 0.495 \\
Chest width & 0.196 & 0.05 & -0.48 \\
Withers height & 0.256 & -0.055 & 0.063 \\
Barrel girth & 0.213 & 0.015 & 0.062 \\
Fore arm length & 0.123 & -0.053 & 0.268 \\
Fore cannon length & 0.232 & 0.151 & 0.072 \\
Fore pastern length & 0.202 & 0.094 & -0.07 \\
Fore cannon midpoint & 0.252 & -0.012 & 0.097 \\
circumference & & & \\
Fore pastern circumference & 0.241 & 0.034 & 0.14 \\
Fore hoof length & -0.0631 & 0.556 & 0.195 \\
Space under horse & 0.214 & -0.274 & -0.012 \\
Pelvis width distance & 0.2096 & 0.218 & -0.314 \\
Length of croup to dock & 0.241 & -0.089 & 0.163 \\
Gaskin length & 0.197 & 0.191 & -0.311 \\
Hind cannon length & 0.246 & 0.064 & -0.056 \\
Hind cannon midpoint & 0.235 & -0.1136 & 0.14 \\
circumference & & & \\
Hind pastern length & 0.219 & 0.121 & -0.034 \\
Hind pastern circumference & 0.242 & -0.0342 & 0.072 \\
Hind hoof length & -0.402 & 0.581 & 0.098 \\
\hline & & & \\
\hline
\end{tabular}

In all significant variants, Caspian had the lowest mean compared to the others. Therefore, it could be concluded that Caspian has the smallest size as compared to the others. In addition, the means of most traits in Kurdish and Turkoman were close to each other (the levels of significance are 0.05 and 0.01) (Table 2).

\section{DISCUSSION}

The results of our investigation strongly support the previous observations on the presence of significant difference among three breeds of horse in Iran i.e., Turkoman, Kurdish, and Caspian. Morphometric investigation of Gabriel et al. (1998) on horse breeds revealed that the smallest sizes of equine navicular bone in ponies and horses were consistently found in low weight pony and hybrid race horse, respectively. The biggest of equine navicular bone was found in the high weight hybrid. Cortical bone had been increased in race horse in order to produce a Cancellus bone; subsequently it would lead to an increase in the production of bone in Corticoendosteal junction (Baggot \& Russel, 1988). Also in another histomorphometryic survey, it showed that tendon/ligament measures of Thoroughbreds were significantly larger than Arabian horse (Carter et al., 2009). Weller et al. (2006) demonstrated significant differences in joint angles and segment lengths among races of horses in France and Ireland. Concerning single breed morphometric investigations, Cervantes et al. (2009) showed the presence of significant difference in shape and size of the Arabian horse in Spain.

The results of this study demonstrated that Caspian had utterly smaller size and different morphometric appearances than the others. On the other hand, Kurdish and Turkoman were similar to each other as was shown by the similar morphometric appearances. This result

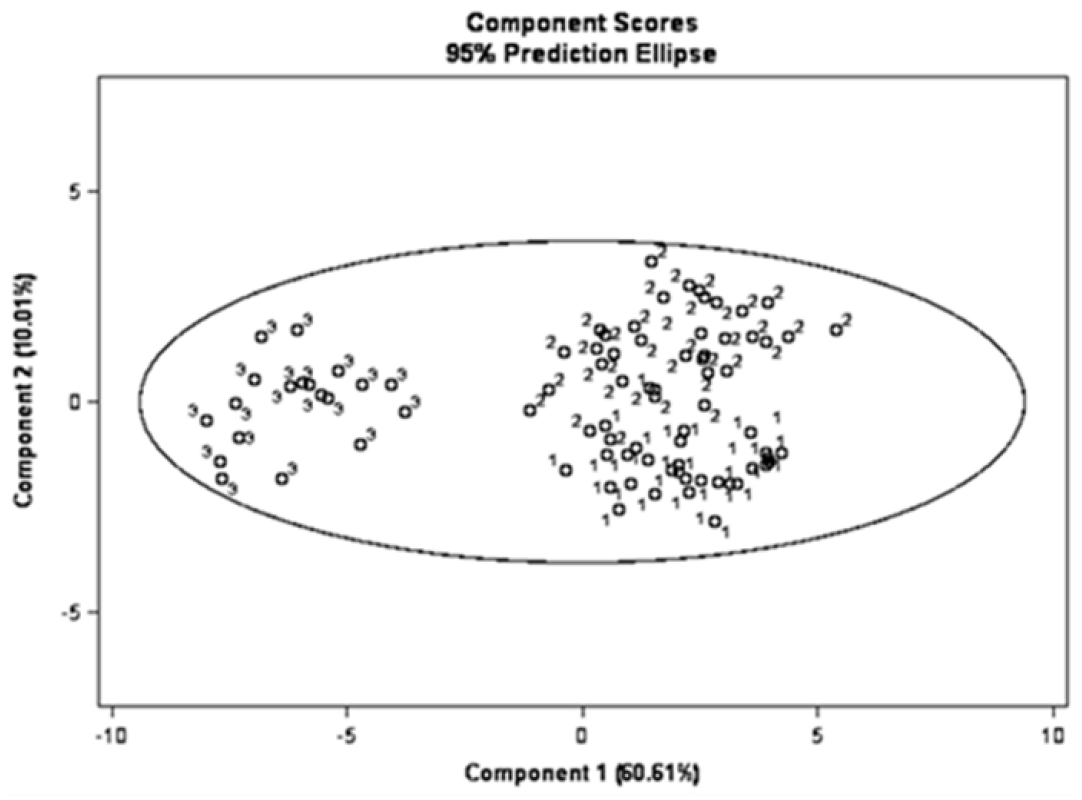

Figure 4. Scatter plot of principal component analysis (PCA) based on PC1 and PC2; the numbers 1, 2, and 3 are indication of Turkoman, Kurdish, and Caspian breeds, respectively. 
Turkoman

Caspian

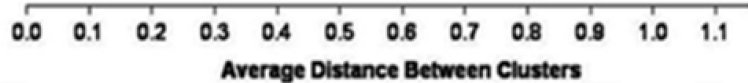

Figure 5. Dendrogram plotted by UPGMA method based on the cluster analysis among the breeds

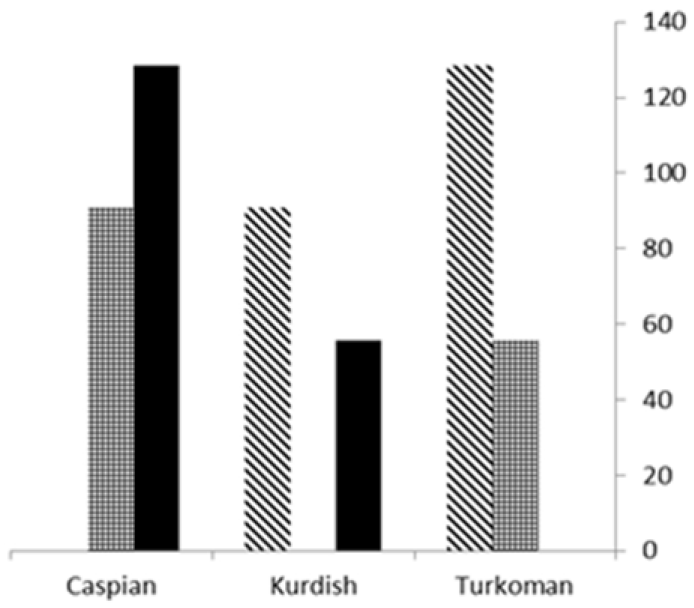

Figure 6. Squared mahalonobis distances among the breeds -Turkoman; \# Kurdish; s Caspian

Table 2. Basic statistics of the main morphometric features, ${ }^{*}$ and ${ }^{* *}$ indicates signification in the levels 0.05 and 0.01 , respectively, based on ANOVA (all of variable measured in conformity with centimeter $(\mathrm{cm})$ )

\begin{tabular}{|c|c|c|c|c|c|c|c|}
\hline \multirow{2}{*}{ Variable } & \multicolumn{2}{|c|}{ Turkoman } & \multicolumn{2}{|c|}{ Kurdish } & \multicolumn{2}{|c|}{ Caspian } & \multirow{2}{*}{$\begin{array}{c}\text { All breeds } \\
\text { Mean }\end{array}$} \\
\hline & Mean & $\mathrm{SD}$ & Mean & $\mathrm{SD}$ & Mean & SD & \\
\hline Head length** & 55.90 & 2.60 & 52.84 & 2.65 & 44.90 & 4.30 & 51.21 \\
\hline Eye to eye widthns & 17.42 & 1.02 & 16.90 & 1.22 & 14.83 & 2.50 & 16.38 \\
\hline Ear length* & 14.14 & 1.05 & 13.90 & 1.64 & 11.00 & 1.30 & 13.01 \\
\hline Neck circumference ${ }^{* *}$ & 70.91 & 5.20 & 73.40 & 6.62 & 61.20 & 4.70 & 68.50 \\
\hline Neck length** & 68.51 & 11.20 & 70.01 & 10.03 & 57.04 & 9.70 & 65.18 \\
\hline Chest width* & 36.97 & 3.80 & 43.50 & 8.70 & 19.31 & 2.60 & 33.26 \\
\hline Withers height ${ }^{* *}$ & 149.61 & 7.50 & 140.93 & 6.90 & 119.32 & 10.78 & 136.60 \\
\hline Barrel girth** & 168.10 & 13.80 & 163.00 & 13.21 & 133.75 & 9.10 & 154.95 \\
\hline Fore arm length* & 47.17 & 6.90 & 42.40 & 3.60 & 36.30 & 7.40 & 41.95 \\
\hline Fore cannon length* & 27.00 & 2.00 & 27.10 & 2.60 & 21.41 & 2.00 & 25.17 \\
\hline Fore pastern length* & 11.78 & 1.42 & 11.68 & 1.60 & 8.11 & 1.40 & 10.52 \\
\hline Fore cannon midpoint circumference & 18.16 & 1.22 & 17.26 & 1.20 & 14.30 & 1.10 & 16.56 \\
\hline Fore pastern circumference ${ }^{*}$ & 17.83 & 1.34 & 16.92 & 1.23 & 14.12 & 1.25 & 16.29 \\
\hline Fore hoof lengthns & 6.41 & 1.60 & 6.51 & 0.92 & 7.02 & 1.30 & 6.64 \\
\hline Space under horse ${ }^{* *}$ & 87.66 & 7.03 & 78.37 & 7.20 & 62.51 & 9.75 & 76.17 \\
\hline Pelvis width distance ${ }^{* *}$ & 48.82 & 6.20 & 54.47 & 6.95 & 35.20 & 5.00 & 46.16 \\
\hline Length, croup to dock ${ }^{* *}$ & 48.78 & 6.24 & 54.60 & 4.61 & 34.74 & 6.60 & 46.04 \\
\hline Gaskin length** & 51.23 & 3.48 & 41.80 & 4.50 & 42.21 & 4.44 & 45.08 \\
\hline Hind cannon length** & 40.48 & 7.03 & 54.60 & 4.90 & 29.10 & 4.92 & 41.39 \\
\hline Hind cannon midpoint circumference ${ }^{* *}$ & 20.30 & 1.36 & 40.30 & 1.90 & 15.72 & 1.90 & 25.44 \\
\hline Hind pastern length* & 12.35 & 1.94 & 18.50 & 1.30 & 8.10 & 1.94 & 12.98 \\
\hline Hind pastern circumference ${ }^{* *}$ & 19.10 & 1.57 & 11.74 & 1.31 & 15.05 & 1.43 & 15.29 \\
\hline Hind hoof lengthns & 6.15 & 1.49 & 6.75 & 1.13 & 7.00 & 0.80 & 6.63 \\
\hline
\end{tabular}

could be justified by natural selection. Body size is a critically important trait in nearly all horse breeds and it presumably is under a strong selection. Natural selection selects for complex traits such as body size to improve the function and the fitness of the breed. In many cases, different environment conditions create different species and breeds, usually with different morphological traits. The more different the environmental conditions are, the more different the morphological traits among species will be. Turkoman and Kurdish have the same habits compared to Caspian. This similar habit leads to the resemblance between Turkoman and Kurdish and more morphological difference from the Caspian breed. Also paleontological investigations demonstrate that primitive horses had the same size as dogs. However, the same is not true for nowadays and 
it shows the size evolution of horses. Therefore the size of horse is a factor in which there is a possibility of its variability among different breeds in response to the changes in the environmental conditions. By the way, Brooks et al. (2010) classified Caspian into Welsh Mtn. Pony, Welsh pony, and Shetland pony, amongst 65 horse breeds.

According to PCA, hind hoof length had the most contribution to the changes. It suggested that hind hoof length is a valuable feature for morphometric studies in horses. On the other extreme this result shows that hind hoof length is more variable than other features. By the way, Sobczuk \& Komosa (2012) demonstrated the largest discriminative power in PCA, in order to differentiate Polish Arabian horses from three leading stud farms are the length of the metatarsus, pelvis, arms, and the depth of the chest and neck. The reason for the high variability of hind hoof length in our results might be explained by the breed fitness. Environmental adaptation ensures that once the attributes of the species have provided themselves the effective functions, the species will persist. The presence of high variability in hind hoof length implies that the environment affects this trait more than the other traits. Due to the relationship between the changes of hind hoof length and horse speed and jumping ability, it could be concluded that the presence of difference between habits and application among the breeds, and subsequently difference among jumping and speed ability, the final result is the variability in this trait.

All in all, evolution of horses causes the changes of size trait among the breeds and this evolution is in the direction of adaption to the nature and fitness.

\section{CONCLUSION}

Our results showed too much differences of morphometrical traits among three Iranian horse breeds of Turkoman, Kurdish, and Caspian. Caspian had smaller size than the others and it was separated from each other based on 23 morphometric traits. The most variable trait among the breeds was hind hoof length.

\section{REFERENCES}

Brooks, S. A., S. Makvandi-Nejad, E. Chu, J. J. Streeter, C. Allen, E. Gu, B. McCleery, B. A. Murphy, R. Bellone, \& N. B. Sutter. 2010. Morphological variation in the horse: defining complex traits of body size and shape. Anim. Genet. 41: 159-165. http://dx.doi.org/10.1111/j.1365-2052.2010.02127.x

Baggot, D. G. \& A. M. Russel. 2007. Lameness in dairy cattle. Brit. Vet. J. 137: 114-132.

Carter, R. A., G. Raymond, J. Staniar, W. B. Cubitt, T. A. Harris, \& A. Pat. 2009. Apparent adiposity assessed by standardised scoring systems and morphometric measurements in horses and ponies. Vet. J. 179: 204-210. http:// dx.doi.org/10.1016/j.tvjl.2008.02.029

Cervantes, I., R. Baumung, A. Molina, T. Druml, J. P. Gutiérrez, J. Sölkner, \& M. Valera. 2009. Size and shape analysis of morphofunctional traits in the Spanish Arab horse. Livest. Sci. 125: 43-49. http://dx.doi.org/10.1016/j.livsci.2009.03.006

Gabriel, A., S. Jolly, J. Detilleux, C. Dessy-Doizé, B. Collin, \& J. Reginster. 1998. Morphometric study of the equine navicular bone: variations with breeds and types of horse and influence of exercise. J. Anat. 193: 535-549. http:// dx.doi.org/10.1046/j.1469-7580.1998.19340535.x

Hendricks, B. L. 2007. International encyclopedia of horse breeds. 1st ed. Oklahoma, USA, University of Oklahoma Press Publisher.

Ruggiero, L. F., K. B. Aubry, S. W. Buskirk, G. M. Koehler, C. J. Krebs, K. S. McKelvey, \& J. R. Squires. 1999. Ecology and conservation of lynx in the United States. Rocky Mountain Mesearch Station. 1: 351-371.

SAS Institute. 2013. SAS software. Version 9.3. SAS Inc. Cary NC.

Slice, D. E. 2007. Geometric morphometrics. Annu. Rev. Anthropol. 36:261-281. http://dx.doi.org/10.1146/annurev. anthro.34.081804.120613

Sobczuk, D. \& M. Komosa. 2012. Morphological differentiation of Polish Arabian horses-multivariate analysis. B. Vet. I. Pulawy. 56: 623-629. http://dx.doi.org/10.2478/ v10213-012-0110-5

Weller, R., T. Pfau, S. A. May, \& A. M. Wilson. 2006. Variation in conformation in a cohort of National Hunt racehorses. Equine Vet. J. 38: 616-621. http://dx.doi. org/10.2746/042516406X150394 